\title{
İki farklı yaklaşıma dayalı bilimin doğası öğretiminin fen bilgisi öğretmen adaylarının kavram yanılgılarının giderilmesindeki etkisi ${ }^{[*]}$
}

\author{
Fatma ÖNEN ÖZTÜRK ${ }^{[* *]}$ \\ Hale BAYRAM ${ }^{[* * *]}$
}

\begin{abstract}
Öz
Çağdaş bilim anlayışıyla birlikte toplumdaki bireylerin bilime ve bilimsel çalışmalara yönelik bakış açısı da değişmiştir. Bu durum bilimsel okuryazarlık ve bilimin doğası gibi farklı başlıklara verilen önemi de arttırmıştır. Bu araştırmanın amacı, doğrudan-yansıtıcı ve dolaylı yaklaşıma dayalı bilimin doğası öğretim uygulamalarının, fen bilgisi öğretmen adaylarının bilimin doğası hakkındaki kavram yanılgılarının giderilmesine etkisinin belirlenmesidir. Araştırma 2008-2009 eğitim-öğretim yılı güz döneminde İstanbul'daki bir devlet üniversitesinde gerçekleştirilmiştir. Araştırmaya 43 fen bilgisi öğretmen adayı katılmıştır. Öğretmen adayları seçkisiz olarak Grup I ve Grup II olarak iki gruba ayrılmışlardır. Bilimin doğası ve boyutları Grup I de yer alan öğrencilere doğrudan-yansıtıcı, Grup II'de yer alan öğrencilere dolaylı yaklaşımla öğretilmiştir. Araştırma verileri VNOS-C ölçeği, görüşme soruları ve video kayıtları ile toplanmıştır. Araştırma verileri içerik analizi ile değerlendirilmiştir. Araştırmada görüşme ve video kayıtlarından elde veriler ise veri çeşitlemesi amacıyla kullanılmıştır. Araştırmadan elde edilen sonuçlar öğretmen adaylarının; bilimsel teori ve kanunlar, bilimsel bilginin değişebilir ve deneysel doğası gibi literatürde de yeralan farklı yanılgılara sahip olduklarını ortaya koymaktadır. Araştırmadan elde edilen sonuç; doğrudan-yansıtıcı yaklaşımla gerçekleştirilen öğretimin, kavram yanılgılarının giderilmesi konusunda dolaylı yaklaşıma göre daha etkili olduğunu ortaya koyar niteliktedir.
\end{abstract}

Anahtar kelimeler: Bilimin doğası, doğrudan-yansıtıcı yaklaşım, dolaylı yaklaşım, fen eğitimi, fen bilgisi öğretmen adayı.

[*] Bu çalışma doktora tez çalışmasından üretilmiştir.

${ }^{[* *]}$ Dr., Marmara Üniversitesi, Atatürk Eğitim Fakütesi, İlköğretim bölümü, Fen Bilgisi Öğretmenliği ABD, fatma_onen@hotmail.com, fatma.onen@marmara.edu.tr

${ }^{[* * *]}$ Prof. Dr., Marmara Üniversitesi, Atatürk Eğitim Fakütesi, İlköğretim bölümü, Fen Bilgisi Öğretmenliği ABD, haleb@marmara.edu.tr 


\title{
The effect of nature of science teaching based on two different approaches on the elimination of prospective science teachers' misconceptions
}

\begin{abstract}
Along with the modern understanding of science, the viewpoints of individuals in the society towards science and scientific studies have also changed. This situation has also increased the importance given to different titles such as scientific literacy and the nature of science. The purpose of this study is to determine the influence of the teaching method of the nature of science carried out with explicit-reflective and implicit approach on the elimination of misconceptions of science teacher candidates about the nature of science. The research was carried out in the Fall semester of 2008-2009 academic year. The number of participants of the research was 43 science teacher candidates in a public university in Istanbul. Participants of the research was selected rondamly and assigned to Group I and Group II. Group I was taught with the method based on explicitreflective and Group II was taught with method based on implicit teaching approach. Research data were collected through the VNOS-C scale, interview questions and video records. Research data were evaluated with content analysis. The data obtained from interviews and video records in the research were used for triangulation. The results obtained from the research revealed that both groups have different misconceptions, such as scientific theory and laws, the experimental and tentative nature of science. The result of the research also revealed that the teaching method carried out with explicit-reflective approach is more effective in the elimination of misconceptions of prospective science teachers on the nature of science in comparison to implicit approach.
\end{abstract}

Keywords: Nature of science, explicit-reflective approach, implicit approach, science education, prospective teacher.

\section{Giriş}

Milli Eğitim Bakanlığı’nın (MEB) 2006 yılında uygulamaya koyduğu fen ve teknoloji öğretim programının temel amacı; öğrencilerin derste görmüş oldukları konular ile günlük yaşam arasındaki ilişkiyi kurmalarını sağlayarak, bilimsel okuryazar öğrenciler yetiştirmektir. Nitekim Ayvacı ve Özbek (2015) de bireylere bilimin özelliklerini öğretmek gerektiğini belirtirken; bu durumun bireylere bilimsel düşünme becerisi kazandırma, bilimsel içeriği daha iyi kavramayı sağlama ve bilime karşı olumlu bir bakış açısına sahip olma açısından da katkı sağlayacağını ifade etmiştir.

Ulusal Fen Eğitimi Standartlarına göre bilimsel okuryazar birey bilimle ilgili popüler yayınları anlayabilme ve sonuçların geçerliği hakkında tartışmalara katılabilme, ulusal ve yerel konularda karar verebilme, bilimsel ve teknolojik olarak ortaya çıkan konuları tanımlayabilme yeterliğine sahip kişilerdir. Okuryazar bir kişi bilimsel bilgiyi üretmek için kullanılan metotlar ve kaynaklar ile ilgili değerlendirme yapabilmelidir (NRC, 1996, s.22).

Bilimsel okuryazarlık üzerine yapılan vurgunun artmasıyla birlikte, bilimsel okuryazarlığın sağlanması sürecinde önemli bir yeri olan bilimin doğasına ilişkin kavramların kazandırılması 
da ön plana çıkmıştır. Bilimin doğası; bilimin tarihi, sosyolojisi ve felsefesi gibi farklı alanları içeren çeşitli toplumsal çalışmaların; bilimin ne olduğu, nasıl çalıştığı, bilim insanlarının toplumsal yapıyı nasıl idare ettiği ve toplumun bilimsel girişimleri nasıl yönettiği gibi soruların geniş açılamalarını içeren, psikoloji gibi bilişsel bilim araştırmalarının birleşimi doğrultusunda disiplinler arası süren çalışmalar bütünüdür (McComas, Clough ve Almazroa, 2000). Bilimin doğası farklı disiplinlerin bir arada çalışması ile ortaya çıkan bir kavram olmasının yanı sıra, alanda yapılan farklı çalışmalar bu kavrama ilişkin ortak temaların oluşturulabileceğini ortaya koymaktadır. Bu bağlamda bilimin doğası; bilimsel bilginin deneysel doğası, bilimsel bilginin değişebilir doğası, bilimsel bilginin yaratıcı doğası, bilimsel bilginin sosyal ve kültürel doğasıbilimsel bilginin nesnel doğası, bilimsel teoriler ve kanunlar ile bilimde gözlem-çıkarım ilişkisi olmak üzere yedi farklı özellikle karakterize olmaktadır (Lederman, Abd-El Khalick, Bell ve Schwartz, 2002).

Literatürde yer alan farklı çalışmalar, bilimin doğasına yönelik çeşitli sorunların yaşandığını gösterir niteliktedir. Bu sorunların en önemlilerinden biri de gerek öğrenci gerekse öğretmenlerin bilimin doğasına ilişkin yanlış inanışlara sahip olmalarıdır. McComas (2000) bu yanlış inanışları; hipotezler teorilere teoriler de kanunlara dönüşür, bilimsel kanunlar ve benzeri iddialar mutlak doğrudur, hipotezler denenmiş tahminlerdir, genel ve evrensel bir bilimsel metot bulunmaktadir, dikkatlice toplanan kanıtlar kesin bilgiyle sonuçlanmaktadır, bilim ve metotları mutlak kanıtlar sağlamaktadır, bilim yaratıcı olmaktan çok yöntemseldir, bilim ve metotları tüm soruları cevaplamaktadır, bilim insanları nesneldir, deneyler bilimsel bilgiye ulaşmak için temel rotadır, bilimsel sonuçlar doğruluğu açısından gözden geçirilmektedir, yeni bilimsel bilgi hemen kabul edilmektedir, bilimsel modeller gerçeği temsil etmektedir, bilim ve teknoloji aynı şeyi ifade etmektedir, bilim yalnız yapılan bir uğraştır.

Yanlış kavramlara sahip bir öğretmen/öğretmen adayının alanında ne kadar verimli olabileceği tartışılır niteliktedir. Nitekim benzer durum bilimin doğası öğretimi için de söz konusudur. Bilimin doğasına ilişkin yanılgıların giderilebilmesi amacıyla farklı öğretim yaklaşımları kullanılmakta ve bu yaklaşımlar dolaylı, doğrudan-yansıtıcı ve tarihsel olmak üzere üç farklı başlıkta sınıflanmaktadır. Dolaylı yaklaşımı derslerine adapte eden araştırmacılar, genellikle bilimsel süreç becerileri, bilimsel araştırma aktiviteleri veya öğrenme çevresine manipüle ettikleri belirli özellikler yardımıyla bilimin doğasını öğretmeyi amaçlamaktadırlar (Abd-El Khalick ve Lederman, 2000). Doğrudan-yansıtıcı yaklaşım bilimin doğasına ilişkin anlayışın geliştirilmesi sürecinin "ikincil bir yan ürün olmaktan çok planlanmış bir aktivite olması" gerektiği görüşünü savunmaktadır. Billeh ve Hasan’n (1975) belirttiğine göre, bilimin doğası öğretiminde doğrudan yaklaşımı savunan araştırmacıların, doğrudan yaklaşıma göre, bilimin doğası öğretimine yönelik düzenlemiş oldukları öğretim yolları bulunmaktadır (Akt. Küçük, 2006). Tarihsel yaklaşımda ise bilimin doğası anlayışının geliştirilmesi amacıyla, bilim tarihinin fen öğretimine entegre edilmesinin gerekliliğini vurgulamaktadır (Khishfe ve Abd-El Khalick, 2002).

Bilimin doğası öğretiminde kullanılan farklı yaklaşımlar olmakla birlikte; literatürde yer alan araştırmalar doğrudan-yansıtıcı yaklaşım kullanılarak işlenen derslerin, bilimin doğasına ilişkin anlayışları geliştirdiğini ortaya koymaktadır (Khishfe ve Abd-El Khalick, 2002; Rivas, 2003; 
Abd-El Khalick, 2005; Khishfe ve Lederman, 2006; Ayvac1, 2007; Wahbeh, 2009; Köksal, 2010). Araştırmada öğretmen adaylarının sahip oldukları yanlış inanışların, öğretim sürecine yönelik etkisi düşünülerek; bilimin doğasına ilişkin yanlış inanışların belirlenmesi ve farklı öğretim yaklaşımlarının öğretim sürecindeki etkililiğinin belirlenmesi hedeflenmiştir. Ülkemizde bilimin doğasına ilişkin yapılan araştırmalara son yıllarda sıklıkla rastlanmaktadır (Oyman, 2002; Kahyaoğlu, 2004; İrez ve Çakır, 2006; İrez, 2006; Öztuna Kaplan, 2006; Aslan, 2009; Köksal, 2010; Ayvacı ve Özbek, 2015; Çelik, 2015; Erdoğan ve Köseoğlu, 2015; İmer Çetin ve Taşar, 2015; Yenice, Özden ve Balcı, 2015; Yüce ve Önel, 2015; Yücel Dağ, 2015; Boran ve Bağ, 2016; Çıbık, 2016; Göksu, Aslan, Özel ve Şenel Zor, 2016). Buna karşın ulusal literatürde yanılgıların giderilmesine yönelik az sayıda araştırmaya rastlanmıştır (Çelik ve Bayrakçeken, 2006; Ayvacı, 2007; Akçay, 2011; Nalçacı, Akarsu ve Kariper, 2011; Hastürk, Öztürk, Demir, ve Kartal, 2014; Çelik, 2015; Erdoğan ve Köseoğlu, 2015; Ağlarcı ve Kabapınar, 2016; Göksu vd., 2016). Bu bağlamda bu araştırmanın öğretmen adaylarının kavram yanılgılarının tespit edilmesi ve bu süreçte farklı yaklaşımların etkililiğine ilişkin sonuçları ortaya koyması açısından alana katkı sağlayacağı düşünülmektedir. $\mathrm{Bu}$ araştırmada fen bilgisi öğretmen adaylarının bilimin doğasına ilişkin mevcut görüşlerinin belirlenerek bilimin doğasına ilişkin yanlış inanışlarının tespit edilmesi ve uygulanan farklı ögretim yaklaşımlarının bu inanışlara olan etkisinin belirlenmesi amaçlanmıştır. Bu bağlamda araştırmada doğrudan-yansıtıcı ve dolaylı yaklaşımla yürütülen bilimin doğası öğretim uygulamalarının, fen bilgisi öğretmen adaylarının bilimin doğası hakkındaki yanlış inanışlarına yönelik etkisinin belirlenmesi amaçlanmıştır.

\section{Yöntem}

\section{Araştırmanın deseni, çalışma grubu ve uygulanması}

Araştırma 2008-2009 eğitim-öğretim yılı güz döneminde gerçekleştirilmiş olup; araştırmaya İstanbul'daki bir devlet üniversitenin ilköğretim bölümü fen bilgisi öğretmenliği anabilim dalı birinci sınıfında okuyan 43 öğretmen adayı katılmıştır. Araştırmaya katılan öğretmen adayları 'Genel Kimya I' dersini alan öğrenciler arasından Grup I (n=23) ve Grup II ( $n=20)$ olarak rastgele seçilmiştir.

Araştırma, Genel Kimya I dersi müfredatında yer alan atom, periyodik cetvel ve kimyasal bağlar konuları temel alınarak düzenlenmiş ve bizzat araştırmacının katılımıyla birlikte sekiz hafta sürmüştür. Araştırmada Grup I’e doğrudan-yansıtıcı ve Grup II’ye dolaylı öğretim yaklaşımına göre tasarlanmış öğretim uygulanmıştır.

\section{Grup I öğretim planının uygulanması}

Grup I'de yürütülen derslerde araştırmacı, konular işlendikten sonra, müfredattan bağımsız olarak, ders dışı aktiviteler uygulamış ve öğretmen adaylarıyla bilimin doğası boyutlarını tartışmıştır. Grup I'de yürütülen derslerde "gizemli ayak izleri”, "küpler”, "süt çiçekleri”, "genç mi? yaşlı mı?”, “yaşlanan öğretmen”, “tüpler”, “yüzer mi? batar mı?” ve "hipotez kutuları” olmak 
üzere literatürde de yer alan (Lederman ve Abd-El Khalick, 1998; Khishfe, 2004; Küçük, 2006) ve bilimin doğası öğretiminde kullanılan sekiz farklı aktivite kullanılmıştır.

Aktivitelerin her biri bir haftalık zaman dilimi içerisinde uygulanmış ve öğretmen adaylarının 4-5 kişiden oluşan gruplar kurarak, grup çalışması yapması sağlanmıştır. Uygulanan aktivitelerin her biri araştırmacı tarafından sınıfa sunulan bir deney, model veya resimle görsel hale getirilmiş; ardından bilimin doğası anlayışını kazandıracak nitelikte hazırlanmış, doğrudan-yansıtıcı sorularla tartışma yapılmıştır.

Bu amaçla yürütülen ilk ders olan "gizemli ayak izleri" aktivitesinde; bilimde gözlem-çıkarım ilişkisi, bilimsel bilginin öznel ve yaratıcı doğası boyutları tartışılmıştır. Aktivitede öğretmen adaylarına sırasıyla üç farklı şekil dağıtılmış ve şekillere ilişkin ne düşündüklerini açıklamayarak, bir hikaye oluşturmaları istenmiştir. Bu sürecin ardından öğretmen adaylarına aynı şekilleri incelemiş olmalarına rağmen, neden farklı hikâyeler yazdıklarını açıklamaları beklenmiştir. Bilim insanlarının yapmış oldukları çalışmalar örnek gösterilerek, onlarında aynı verileri kullanmalarına rağmen birbirlerinden farklı sonuçlar bulup bulmadıkları sorusu sorularak, bilimsel bilginin öznel doğası üzerine odaklanılmıştır. Öğretmen adaylarının hikâyeleri nasıl yazdıkları, ne tip incelemelerde bulundukları, ön bilgilerini kullanıp kullanmadıkları, hayal gücü ve yaratıcılıklarının bu süreçte etkili olup olmadığı sorularak bilimde gözlem-çıkarım ilişkisi ve bilimsel bilginin yaratıcı doğası üzerine odaklanılmıştır.

\section{Grup II öğretim planının uygulanması}

Grup II'de yürütülen dersler ise geleneksel yöntemle yürütülmüş ve derslerin temelini Genel Kimya I müfredatında yer alan konuların öğretilmesi, ayrıca bu süreçte konuya ilişkin farklı problemlerin çözülmesi oluşturmuştur. Bu grupta yürütülen derslerin Grup I'de yürütülen derslere paralel bir şekilde sürdürülmesi amaçlanmıștır. Buna göre işlenen derslerin süre açısından birbirine denk olması hedeflenmiş; bu amaçla dersler işlendikten sonra, öğretmen adaylarına konuya ilişkin farklı problemler sorularak çözdürülmüsstür. Bu grupta yürütülen geleneksel yöntemle işlenen dersler, bilimin doğası öğretiminde kulanılan yaklaşımlardan biri olan "dolaylı yaklaşımla" uyum göstermektedir. Bu nedenle elde edilen sonuçların, dolaylı öğretim yaklaşımının etkililiğine ilişkin veri sağlayacağı düşünülmektedir.

\section{Araştırma verilerinin toplanması}

Araştırmada öğretmen adaylarının bilimin doğasına ilişkin anlayışların belirlenmesi amacıyla "bilimin doğası hakkında görüşler ölçeği (Views of Nature of Science Qustionnaire-C (VNOS-C)", görüşme soruları ve video kayıtları” kullanılmıştır.

Araştırmada açı uçlu sorulardan oluşan ve birçok araştırmada da (Turgut, 2005; Friedman, 2006; Kim, 2007) kullanılan, VNOS-C ölçeği kullanılmıştır. Bu ölçek öğretim planı uygulanmadan önce ve sonra olmak üzere iki kez uygulanmıştır. Türkçe’ye uyarlama çalışması 2005 yılında Turgut tarafından yapılan ölçek 10 açık uçlu sorudan oluşmakta ve katılımcıların görüşlerini bilimin doğasının 7 alt boyutu doğrultusunda belirlemeyi hedeflemektedir. 
Araştırmada öğretmen adaylarının görüşlerinin daha detaylı bir şekilde inceleyebilmek amacıyla yarı yapılandırılmış görüşme yapılmıştır. Görüşme soruları, VNOS-C ölçeğinde yer alan sorular temel alınarak hazırlanmış; ayrıca bazı sorular literatür taraması doğrultusunda tespit edilmiştir. Görüşme, araştırmaya katılan gruplar içerisinden seçilen altışar öğretmen adayı ile yapılmıştır.

Bunun yanı sıra araştırmada yürütülen derslerin tamamı, kayıt altına alınmıştır. Video kaydı yapılmadan önce öğretmen adaylarına; bu kayıtların ne amaçla yapıldığı, kayıtların her hangi biri tarafından izlenmeyeceği ve bireysel gizliliğe saygı duyulacağı gibi farklı konularda açıklama yapılmıştır.

\section{Araştırma verilerinin analizi}

Araştırmada öğretmen adaylarının bilimin doğası anlayışlarının belirlenmesi amacıyla uygulanan ölçekten elde edilen cevaplar, "içerik analizi” ile değerlendirilmiştir. Buna göre sorular önce kodlanmış, ardından kodlar temalar haline dönüştürülmüştür. Temalar oluşturulduktan sonra her bir temaya ilişkin cevaplama sıklı̆̆ı (f) belirlenerek basit yüzdelik hesaplama yapılmış ve sonuçlar tabloştırılarak sunulmuştur.

Araştırmada kullanılan video ve görüşme kayıtlarının yazıya aktarılmasının ardından, kayıtlar tekrar dinlenmiş; böylece varsa hataların düzeltilmesi sağlanmıştır. Video kayıtları ve görüşme kayıtlarından elde edilen veriler araştırma verilerinin çeşitlemesinde kullanılmış; bu bağlamda ölçekten elde edilen kodlar ve savlar doğrultusunda analiz edilerek gerekli görüldügü durumlarda, elde edilen sonuçları desteklemek ve veri çeşitlemesi yapmak amacıyla kullanılmıştır.

Araştırmanın geçerlik ve güvenirliğini sağlamak amacıyla araştırmacı çeşitlemesi yapılmıştır. Araştırmanın verileri alanda uzman ikinci bir araştırmacı tarafından daha incelenmiş; verilerin tutarlılığı ise Patton’un (2002) belirttiği şekilde yapılmıştır. Yapılan analiz sonrasında araştırmacılar arasındaki tutarlılık \%78 olarak belirlenmiştir. Bunun yanı sıra araştırma verilerinin toplanmasında farklı veri toplama araçları kullanılmış, böylece veri çeşitlemesi yapılmıştır. Araştırmanın geçerlik ve güvenirliğinin arttırılması amacıyla veri toplama süreci, bu süreçte kullanılan ölçme araçları, verilerin nasıl analiz edildiği gibi başlıklar ayrıntılı bir şekilde açıklanmış; ve sorulara ilişkin yanıtlar birebir alıntılarla örneklenmiştir.

\section{Bulgular}

Araştırma bulguları, bilimin doğasının alt boyutları doğrultusunda analiz edilerek tablolaştırılmış ve yorumlanmıştır.

\section{Bilimsel bilginin deneye dayalı doğasına ilişkin bulgular}

Öğretmen adaylarının bu boyuta ilişkin düşünceleri VNOS-C ölçeğinde yer alan "bilimsel bilginin oluşturulmasında "deney gerekli midir?” ve "deney nedir?" soruları ile belirlenmiştir. Soruya ilişkin uygulama öncesi ve sonrasından elde edilen bulgulara Tablo 1'de yer verilmiştir. 
Tablo 1

Bilimsel Bilginin Deneysel Doğasına Illişkin Bulgular

\begin{tabular}{|l|c|c|c|c|c|c|c|c|}
\hline & \multicolumn{3}{|c|}{ Grup I (Doğrudan-yansıtıcı yaklaşım) } & \multicolumn{4}{c|}{ Grup II (Dolaylı yaklaşım) } \\
\cline { 2 - 9 } & \multicolumn{2}{|c|}{ Uygulama öncesi } & \multicolumn{2}{c|}{ Uygulama sonrası } & \multicolumn{2}{c|}{ Uygulama öncesi } & \multicolumn{2}{c|}{ Uygulama sonrası } \\
\cline { 2 - 9 } & $\mathrm{f}$ & $\%$ & $\mathrm{f}$ & $\%$ & $\mathrm{f}$ & $\%$ & $\mathrm{f}$ & $\%$ \\
\hline Deney gereklidir & 22 & 96 & 18 & 78 & 20 & 100 & 18 & 90 \\
\hline Deney gerekli değildir & - & - & 5 & 22 & - & - & 2 & 10 \\
\hline
\end{tabular}

Tablo 1'de de görüldüğü gibi Grup I'deki öğretmen adaylarının \%96'sı uygulama öncesinde deneyin gerekli olduğunu belirtirken; uygulama sonrasında bu şekilde düşünen öğretmen adaylarının oranının \%78'e düştüğü görülmektedir. Grup II’deki öğretmen adaylarının tamamı ise uygulama öncesinde deneyin gerekli olduğunu belirtirken; uygulama sonrasında yalnızca iki öğretmen adayının bu konudaki görüşlerinin farklılaştığ görülmektedir. Araştırmadan elde edilen bu sonuç öğretmen adaylarının uygulama öncesi ve sonrasında deneylerin bilimsel bilgiye ulaşmak için temel rota olması gibi yanlış bir inanışa sahip olduklarını da göstermektedir. Bunun yanı sıra Tablo 1'de de görüldüğü gibi uygulama sonrasında Grup I'deki öğretmen adaylarının bu konudaki yanlış inanışlarının uygulama sonrasında \%78’e; Grup II'de ise \%90’a düştüğü görülmektedir. Öğretmen adaylarının uygulama öncesi ve sonrası için vermiş oldukları yanıtlara ilişkin alıntılara aşağıda yer verilmiştir.

Hayır, gerekli değildir. Felsefe de bir bilim dalıdır ama deney yapılamaz. Tarihte mesela, tarihte deney olabilir mi? Olamaz. Grup I-Ö3 (uyg. sonr.)

Kesinlikle gereklidir. Çünkü bilim somutluk ister. Kurulan hipotezin doğruluğu için ikna edici nedenler ister. Grup II -Ö23 (uyg. önc.)

Benzer sonuçlar sınıf içi tartışmalarda da tespit edilmiştir.

A: Bilimsel çalışmalarda bilim insanları birbirlerini nasıl ve ne tip çalışmalarla ikna ederler? Ö11: Kanit sunarak bilgiyi kabul ettirirler.

Ö11: Deney yaparlar.

Ö21: Karşıdaki kişi ikna edici bir şekilde bir fikir ortaya atarlar.

Ö8: Deney gerekli bence.

\section{Bilimsel bilginin değişebilir doğasına ilişkin bulgular}

Öğretmen adaylarının bu boyuta yönelik görüşleri VNOS-C ölçeğindeki "bilim adamları bilimsel bir teori geliştirdikten sonra (mesela atom teorisi, evrim teorisi) bu teori değişime uğrar mı?' sorusuyla belirlenmiştir. Soruya ilişkin bulgulara Tablo 2'de yer verilmiştir. 
Tablo 2

"Bilimsel Bilginin Değişebilir Doğasına Illişkin Bulgular

\begin{tabular}{|l|c|c|c|c|c|c|c|c|}
\hline \multirow{2}{*}{} & \multicolumn{3}{|c|}{ Grup I (Doğrudan-yansitıcı yaklaşım) } & \multicolumn{4}{c|}{ Grup II (Dolaylı yaklaşım) } \\
\cline { 2 - 9 } & \multicolumn{2}{|c|}{ Uygulama öncesi } & \multicolumn{2}{c|}{ Uygulama sonrası } & \multicolumn{2}{c|}{ Uygulama öncesi } & \multicolumn{2}{c|}{ Uygulama sonrası } \\
\cline { 2 - 9 } & $\mathrm{f}$ & $\%$ & $\mathrm{f}$ & $\%$ & $\mathrm{f}$ & $\%$ & $\mathrm{f}$ & $\%$ \\
\hline Teoriler değişir & 21 & 91 & 22 & 96 & 20 & 100 & 20 & 100 \\
\hline Teoriler değişmez & 2 & 9 & 1 & 4 & - & - & - & - \\
\hline
\end{tabular}

Tablo 2'de de görüldüğü gibi Grup I'deki öğretmen adaylarına ilişkin elde edilen sonuçlar uygulama öncesi ve sonrası açısından karşılaştırıldığında, hem uygulama öncesi hem de sonrasında öğretmen adaylarının büyük bir çoğunluğunun (\%91-\%96) teorilerin değişeceğini düşündükleri; bunun yanı sıra aksini düşünen öğretmen adaylarının olduğu da görülmektedir. Grup II'deki öğretmen adaylarının tamamı (\%100-\%100) hem uygulama öncesi hem de sonrasında teorilerin değişeceğini belirtmişlerdir. Öğretmen adaylarının vermiş oldukları yanıtlar alıntılarda örneklenmektedir.

Teori tam olarak ispatlanmamıştır. Bu yüzden yerine yeni bilgiler eklenebilir, geliştirilebilir ya da yanlış olduğu kanıtlanabilir. Grup I-Ö3 (uyg. önc.)

Teknoloji ilerledikçe insan daha doğrularını bulur bir öncekinin. Ayrıca teoriler kesinlik taşımadığı için değişmesi mümkündür. Grup II -Ö4 (uyg. sonr.)

Araştırmadan elde edilen bu sonuç öğretmen adaylarının bu konudaki görüşlerinin yeterli olduğunu ortaya koymaktadır. Buna karşın öğretmen adaylarının sınıf içerisinde yapmış oldukları tartışmalarda bilimsel bilginin değişebilirliğine ilişkin görüşlerinde yanılgıların olduğu görülmektedir. Sınıf içerisinde yapılan tartışmalar alıntıda örneklenmektedir.

\section{A: Teori ve kanunlar değişir mi?}

Ö21: Sistem değişti araştırmalar gelişti, tersi bulunur ispatlanırsa değişir.

Ö14: Bilim adamları bilgiyi bulurken deney yapıyor, tahmin yapıyor. Bilgi değişmez.

Öğrenciler: Bilgi kanunsa değişmez, teoriyse değissir.

Ö18: Atom modellerine bakalım. İlk olarak teori halinde. Sürekli olarak bir şey bulunuyor ve bilgi değişiyor. Ama yer çekimi kanunu kesindir. Herkes kabul eder değişmez.

Ö2: Gelecekte olacak şeyler doğrultusunda bilgi değişebilir. Aslında kanun da değişebilir.

Alıntılarda da görüldüğü gibi yapmış oldukları açılamalarda öğretmen adayları teorilerin değişebilir olduğunu ortaya koymakla birlikte; söz konusu kavram "kanun” olunca düşüncelerinin farklılaştığı görülmektedir. Benzer sonuçlar Tablo 3 incelendiğinde de görülmektedir. Tablo 3 incelendiğinde Grup I'deki öğretmen adayları uygulama öncesinde \%48 oranında, uygulama sonrasında ise \%26 oranında teorilerin değişeceği, kanunların ise değişmeyeceğini 
düşünmektedirler. Grup II'deki öğretmen adayları ise uygulama öncesinde \%80, uygulama sonrasında ise \%75 oranında ilgili görüşe katılmaktadırlar. Elde edilen farklı sonuçlarda da görüldügü gibi öğretmen adaylarının bu konuya yönelik görüşleri, bilimsel bilgi niteliğindeki teori ve kanun için farklılık göstermektedir. Bu bağlamda bu boyuta ilişkin yanılgılarının olduğu ve bu yanılgının Grup II’de Grup I’e oranla daha fazla olduğu görülmektedir.

\section{Bilimsel teoriler ve kanunlara ilişkin bulgular}

Öğretmen adaylarının bilimsel teori ve kanunlarla ilişkin görüşleri "teori ve kanun arasında her hangi bir farklılık var mıdır?” sorusu ile belirlenmiştir. Soruya ilişkin bulgulara Tablo 3’te yer verilmiştir.

Tablo 3

Bilimsel Teori ve Kanunlara Ilişkin Bulgular

\begin{tabular}{|c|c|c|c|c|c|c|c|c|}
\hline & \multicolumn{4}{|c|}{$\begin{array}{c}\text { Grup I } \\
\text { (Doğrudan-yansitıcı yaklaşım) }\end{array}$} & \multicolumn{4}{|c|}{$\begin{array}{c}\text { Grup II } \\
\text { (Dolaylı yaklaşım) }\end{array}$} \\
\hline & \multicolumn{2}{|c|}{ Uygulama öncesi } & \multicolumn{2}{|c|}{$\begin{array}{l}\text { Uygulama } \\
\text { sonras1 }\end{array}$} & \multicolumn{2}{|c|}{ Uygulama öncesi } & \multicolumn{2}{|c|}{$\begin{array}{l}\text { Uygulama } \\
\text { sonrası }\end{array}$} \\
\hline & $\mathrm{f}$ & $\%$ & $\mathrm{f}$ & $\%$ & $\mathrm{f}$ & $\%$ & $\mathrm{f}$ & $\%$ \\
\hline Teori değişir, kanun değişmez & 11 & 48 & 6 & 26 & 16 & 80 & 15 & 75 \\
\hline Teori evrensel değildir; kanun evrenseldir & 6 & 26 & 4 & 17 & 4 & 20 & 5 & 25 \\
\hline Teoriler kanıtlanmamıştır, kanun kanıtlanmıştır & 6 & 26 & 5 & 22 & - & - & - & - \\
\hline Teoriler kanunu oluşturur & 2 & 9 & 2 & 9 & 3 & 15 & 2 & 10 \\
\hline
\end{tabular}

Tablo 3’te de görüldüğü gibi Grup I ve II'deki öğretmen adaylarının büyük bir bölümü teori ile kanun arasındaki en önemli farklılığı uygulama öncesi (\%48-\%80) ve sonrasında (\%26-\%75) "teorilerin değişmesi, kanunların değişmemesi" olarak ifade etmişlerdir. Elde edilen bu sonuç her iki gruptaki öğretmen adaylarının kanunlar ve benzeri iddiaların mutlak doğru olduğuna ilişkin yanılgıya sahip olduklarını da göstermektedir. Ancak elde edilen sonuçlarda da görüldüğü gibi bu yanılgıya ilişkin görüşlerin oranının uygulama sonrasında her iki grupta da azaldığı görülmektedir. Bununla birlikte elde edilen bulgular Grup I'deki oranın diğerine göre daha fazla oranda azaldığını da ortaya koymaktadır. Elde edilen bu sonuçların yanı sıra öğretmen adaylarının literatürde yeralan teorilerin kanunlara dönüşmesine ilişkin yanılgılarının olduğu da görülmektedir. Grup I’deki öğretmen adayları uygulama öncesi ve sonrasında soruya aynı oranda (\%9-\%9) katılım gösterirken; Grup II’deki öğretmen adaylarının bu konudaki görüşlerinin uygulama sonrasında azda olsa değiştiği tespit edilmiştir (\%80-\%75). Öğretmen adaylarının vermiş oldukları yanıtlardan örneklere alıntılarda yer verilmiştir.

Evet vardır. Teori tüm bilim adamları tarafindan doğruluğu kanıtlanmamıştır. Kanun ise kesinlikle doğrudur. Grup I -Ö5 (uyg. sonr.)

Bilimsel teori değişebilir. Bilimsel kanun kesinlikle değiștirilemez. Grup II-Ö20 (uyg. önc.) 
Elde edilen bu sonuçlar görüşme sürecinden elde edilen bulgularla da benzerlik göstermektedir. İlgili alıntılara aşağıda yer verilmektedir.

\section{A:Teori ve kanun arasındaki farkı var mıdır?}

Ö8:Teori, yapılan deneylerin sonucunda hepsinde aynı sonuca ulaşılamaması sonucunda teori olarak kalmıştır. Herkes tarafindan kabul edilseydi zaten kanun olurdu. Teori deneye kadar olan kısımdır, kanun ise deneyden sonra olan kısımdır. Yani herkes tarafından kabul gören kısımdır.

Ö1:Kanunlar teoriden gelir. Sonuçta teori doğruda olabilir. Teori olmasının nedeni bu basamă̆a geçmek zorunda olması. Herkes tarafindan kabul edilmeyebilir, ama edilebilir de ben edilmez demişim bunu yanlış söylemişim.

\section{Bilimsel bilginin nesnel doğasına ilişkin bulgular}

Öğretmen adaylarının bilimsel bilginin nesnel doğasına ilişkin anlayışlarını belirlemek amacıyla ölçekte yer alan; "Bilim insanlarının dinozorların yok oluşuna ilişkin farklı hipotezler ortaya atmalarının nedenini açıklayınız?” sorusu ile belirlenmiştir. Elde edilen bulgulara Tablo 4’te yer verilmiştir.

Tablo 4

Bilimsel Bilginin Nesnel Doğasına Illişkin Bulgular

\begin{tabular}{|c|c|c|c|c|c|c|c|c|c|c|c|}
\hline \multicolumn{6}{|c|}{$\begin{array}{l}\text { Grup I (Doğrudan-yansıtıcı yaklaşım) } \\
\text { (Doğrudan-yansıtıcı yaklaşım) }\end{array}$} & \multicolumn{6}{|c|}{$\begin{array}{l}\text { Grup II (Dolaylı yaklaşım) } \\
\text { (Dolaylı yaklaşım) }\end{array}$} \\
\hline \multicolumn{3}{|l|}{ Uygulama öncesi } & \multicolumn{3}{|l|}{ Uygulama sonrası } & \multicolumn{3}{|l|}{ Uygulama öncesi } & \multicolumn{3}{|l|}{ Uygulama sonrası } \\
\hline & f & $\%$ & & f & $\%$ & & $\mathrm{f}$ & $\%$ & & f & $\%$ \\
\hline $\begin{array}{l}\text { Farklı hayal gücüne } \\
\text { sahip olma }\end{array}$ & 5 & 22 & $\begin{array}{l}\text { Farklı hayal gücüne } \\
\text { sahip olma }\end{array}$ & 8 & 35 & Farklı yorum yapma & 8 & 40 & Farklı yorum yapma & 4 & 20 \\
\hline Farklı düşünme & 8 & 35 & Farklı düşünme & 6 & 26 & Farklı düşünme & 5 & 25 & Farklı düşünme & 3 & 15 \\
\hline Farklı ön bilginin olması & 5 & 22 & $\begin{array}{l}\text { Farklı ön bilginin } \\
\text { olması }\end{array}$ & 4 & 17 & $\begin{array}{l}\text { Farklı yöntem } \\
\text { kullanma }\end{array}$ & 4 & 20 & $\begin{array}{l}\text { Farklı yöntem } \\
\text { kullanma }\end{array}$ & 4 & 20 \\
\hline Farklı yorum yapma & 9 & 39 & Farklı yorum yapma & 2 & 9 & $\begin{array}{l}\text { Farklı hayal gücüne } \\
\text { sahip olma }\end{array}$ & 2 & 10 & Farklı gözlem yapma & 3 & 15 \\
\hline & & & $\begin{array}{l}\text { Kişisel özelliklerin } \\
\text { farklı olması }\end{array}$ & 8 & 35 & & & & & & \\
\hline
\end{tabular}

Tablo 4’te görüldüğü gibi öğretmen adayları bilimsel bilginin elde edilmesi sürecinde bilim insanlarının neden farklı hipotezler ortaya attıklarını farklı ifadelerle açıklamışlardır. Mevcut sonuçlara ilişkin alıntılara aşağıda yer verilmiştir. 
Bilimsel bilgiye ulaşmada öznellik vardır. Aynı olaydan farklı yorumlar yapmamız, farklı kişiler olmamız (hayal gücü, düşünce sistemi). Grup I -Ö10 (uyg. sonr.)

Bilim adamlarının hayal gücü ve yorumları sonucu farklı sonuçlara ulaşılmıştır. Grup IIÖ32 (uyg. önc.)

Elde edilen sonuçlar Grup I ve Grup II'deki öğretmen adaylarının uygulama öncesi ve sonrasında, bilimsel bilginin elde edilmesi sürecinde öznelliğin yapılan çalışmaları etkilediği düşüncesinde olduklarını; bu bağlamda bu boyuta ilişkin görüşlerinin yeterli olduğu ve herhangi bir yanılgının yer almadığı görülmektedir.

\section{Bilimsel bilginin yaratıcı doğasına ilişkin bulgular}

Öğretmen adaylarının bilimsel bilginin yaratıcı doğasına ilişkin anlayışlarının belirlenmesi amacıyla ölçekte yeralan "bilim insanları çalışmalarında hayal gücü ve yaratıcılıklarını kullanırlar mı?” sorusu ile belirlenmiştir. Elde edilen bulgulara Tablo 5’te yer verilmiştir.

Tablo 5

Bilimsel Bilginin Yaratıcı Doğasına Illişkin Bulgular

\begin{tabular}{|l|c|c|c|c|c|c|c|c|}
\hline \multirow{2}{*}{} & \multicolumn{2}{|c|}{ Grup I (Doğrudan-yansıtıcı yaklaşım) } & \multicolumn{4}{c|}{ Grup II (Dolaylı yaklaşım) } \\
\cline { 2 - 10 } & Uygulama öncesi & Uygulama sonrası & \multicolumn{2}{c|}{ Uygulama öncesi } & \multicolumn{2}{|c|}{ Uygulama sonrası } \\
\cline { 2 - 9 } & $\mathrm{f}$ & $\%$ & $\mathrm{f}$ & $\%$ & $\mathrm{f}$ & $\%$ & $\mathrm{f}$ & $\%$ \\
\hline Hayal gücü ve yaratıcılık kullanırlar & 23 & 100 & 23 & 100 & 19 & 95 & 20 & 100 \\
\hline Hayal gücü ve yaratıcılık kullanmazlar & - & - & - & - & 1 & 5 & - & - \\
\hline
\end{tabular}

Tablo 5’te de görüldüğü gibi Grup I'deki öğretmen adaylarının tamamı hem uygulama öncesi hem de sonrasında hayal gücü ve yaratıcılığın bilimsel çalışmalarda kullanıldığını belirtmişlerdir. Grup II'deki öğretmen adaylarının da hemen hemen tamamı (\%95) uygulama öncesinde bilimsel çalışmalarda hayal gücü ve yaratıcılığın kullanıldığını belirtmiş; uygulama sonrasında ise tüm öğretmen adaylarını bu görüşte olduğu tespit edilmiştir. Araştırmadan elde edilen sonuçlar öğretmen adaylarının bu boyuta ilişkin görüşlerinin yeterli olduğunu ve her hangi bir yanılgılarının yer almadığını göstemektedir. Sorulara ilişkin verilen yanıtlar aşağıda örneklenmektedir.

Evet, kullandıklarını düşünüyorum. Hayal güçlerini, yaratıcılıklarını kullanmadan tahmin yapamazlar ve bir sonuca ulaşamazlar. Grup I -Ö7 (uyg. sonr.)

Hayal gücünü kullanmazlar. Çünkü bilim adamları bir soruya hayal güçlerini karıştırırlarsa ona göre hareket edeceklerdir ve soru amactndan sapacaktır. Bilimsel bir sorunun cevabı hayal gücüyle değil deneylerle ispatlanır. Grup II -Ö26 (uyg. önc.) 


\section{Bilimde gözlem-çıkarım ilişkisine ait bulgular}

Öğretmen adaylarının gözlem-çıkarım ilişkisine anlayışlarının tespit edilmesi amacıyla ölçekte yeralan 6. ve 7. sorular değerlendirilmiştir. 6. soruda öğretmen adaylarına "bilim insanlarının atomun yapısına ilişkin sonuçları hangi kanıtlardan yola çıkarak belirledikleri”; 7. soruda ise "bilim insanlarının türün ne olduğunu hangi kanıtlardan yola çıkarak belirledikleri" sorulmuştur. Sorulara ilişkin elde edilen bulguların ortak temalar içermesi nedeniyle; bulgulara tek bir tabloda, Tablo 6'da yer verilmiştir.

Tablo 6

Bilimde Gözlem-Çıkarım Ilişkisine Illişkin Bulgular

\begin{tabular}{|l|c|c|l|c|c|c|c|c|c|c|c|}
\hline \multicolumn{4}{|c|}{ Grup I (Doğrudan-yansıtıcı yaklaşım) } & \multicolumn{4}{c|}{ Grup II (Dolayl yaklaşım) } \\
\hline \multicolumn{2}{|c|}{ Uygulama öncesi } & & \multicolumn{2}{|c|}{ Uygulama sonrası } & \multicolumn{3}{c|}{ Uygulama öncesi } & \multicolumn{3}{c|}{ Uygulama sonrası } \\
\hline & $\mathrm{f}$ & $\%$ & & $\mathrm{f}$ & $\%$ & & $\mathrm{f}$ & $\%$ & & $\mathrm{f}$ & $\%$ \\
\hline Deney yaparak & 11 & 48 & Deney yaparak & 18 & 78 & Deney yaparak & 8 & 40 & Deney yaparak & 8 & 40 \\
\hline Araştırma-inceleme yaparak & 8 & 35 & İnceleme yaparak & 2 & 9 & Gözlem yaparak & 6 & 30 & Gözlem yaparak & 2 & 10 \\
\hline Gözlem yaparak & 5 & 22 & Gözlem yaparak & 7 & 30 & $\begin{array}{l}\text { Araştırma-inceleme } \\
\text { yaparak }\end{array}$ & 4 & 20 & $\begin{array}{l}\text { Ön bilgilerini } \\
\text { kullanarak }\end{array}$ & 6 & 30 \\
\hline & & & $\begin{array}{l}\text { Ön bilgileri } \\
\text { yardımıyla }\end{array}$ & 3 & 13 & & & & & & \\
\hline
\end{tabular}

Tablo 6'da da görüldüğü gibi Grup I ve II'deki öğretmen adayları bilim insanlarının yapmış oldukları çalışmaların sonuçlarına uygulama öncesi ve sonrasında sıklıkla deney yaparak (Grup I/ \%48-\%78) (Grup II/\%40-\%40) ulaştıklarını düşünmektedirler. Bunun yanı sıra her iki gruptaki öğretmen adaylarının gözlem, araştırma, inceleme ve ön bilgilerini kullanma gibi farklı çalışmalara ilişkin açıklamada da bulundukları görülmektedir. Ancak öğretmen adayları yapmış oldukları farklı açıklamlara rağmen gözlem-çıkarım ilişkisine yönelik her hangi bir açıklamada bulunmamışlardır. Bu bağlamda öğretmen adaylarının bu konuya yönelik kavramayı tam olarak sağlayamadıkları ve çıkarım yapma kavramını kavrayamadıkları görülmektedir. Öğretmen adaylarının vermiş oldukları yanıtlar aşağıda alıntıda örneklenmektedir.

İlk zamanlarda birçok hipotez atıldı ortaya ama hepsinin eksik bir yönü bulunduğundan geçerli olmadı. Bu tanımı yapabilmeleri için bilim adamları sürekli kontrollü deney ve gözlem yaparak buldular. Grup I-Ö61 (uyg. önc.)

Kesin emin olmak her daim deneylerle kabul olur. Daha önce ortaya konan bilimsel bilgilerden yararlanılabilir. Grup II-Ö6 (uyg. sonr.)

Öğretmen adayları benzer açıklamaları sınıf içi tartışmalarda da yapmışlardır. İlgili alıntı aşağıda örneklenmektedir. 
A:Her hangi bir olaya ilişkin ispat yaparken ne yapıyorsunuz?

Ö5: Ön bilgimiz var, onu kullaniyoruz.

Ö18: Denememiz gerekir

Ö17: Ön bilgilerimizi kullanırken bazı tahminler yaptık, ama gerçekten doğru olup olmadığın anlamamız için deney yapmamız gerekiyordu.

\section{Bilimsel bilginin sosyal ve kültürel doğasına ilişkin bulgular}

Öğretmen adaylarının bilimsel bilginin sosyal ve kültürel doğasına ilişkin anlayışlarının tespit edilmesi amacıyla ölçekte yer alan dokuzuncu soru değerlendirilmiştir. Soruda "bilimin sosyal ve kültürel değerleri mi yoksa evrensel değerleri mi yansittığı” sorulmuştur. Soruya ilişkin elde edilen bulgulara Tablo 7’de yer verilmiştir.

Tablo 7

Bilimsel Bilginin Sosyal ve Kültürel Doğasına llişkin Bulgular

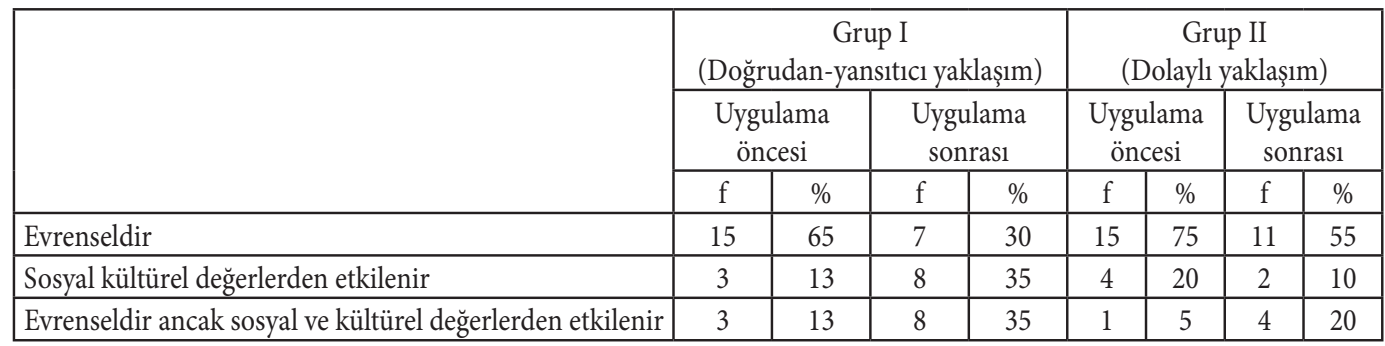

Tablo 7’de de görüldüğü gibi Grup I'deki öğretmen adaylarının büyük bir çoğunluğu (\%65) ön uygulamada bilimin evrensel olduğunu belirtirken; uygulama sonrasında öğretmen adaylarının düşüncelerinin oldukça farklılaştığı (\%30) görülmektedir. Bu sonucun yanı sıra uygulama öncesinde Grup I'deki öğretmen adaylarının \%13'ünün, uygulama sonrasında ise \%35'inin bilimin sosyal-kültürel değerlerden etkilendiğini düşündükleri görülmektedir. Benzer sonuçlar bilimin evrensel olduğunu ancak sosyal-kültüreldeğerlerden etkilendiğini belirten öğretmen adayları için de geçerlidir (\%23-\%35). II. Grup II'deki öğretmen adaylarının çoğunluğu uygulama öncesi ve sonrasında (\%75-\%55) bilimin evrensel olduğunu belirtmişlerdir. Bunun yanı sıra bilimsel bilginin sosyal kültürel değerlerden etkilendiğini belirten öğretmen adaylarının oranının uygulama sonrasında azaldığı (\%20-\%10) Tablo 7'de görülmektedir. Bu sonuca karşın bilimsel bilginin evrensel olduğunu ancak sosyal ve kültürel değerlerden etkilendiğini belirten öğretmen adaylarının oranının arttığı (\%5-\%20) görülmektedir.

Bu boyuta ilişkin elde edilen bulgular, I. gruptaki öğretmen adaylarının görüşlerinin uygulama öncesine göre daha fazla değiştiğini ortaya koymakla birlikte; daha çağdaş görüşlere sahip olduklarını da ortaya koymaktadır. Bu sonucun yanı sıra öğretmen adaylarının bir bölümünün 
halen bilimin evrensel olması yönünde görüş belirttikleri de görülmektedir. II. Gruptaki öğretmen adayları ise oranı azalmakla birlikte; bük bir oranda bilimin evrensel olduğunu belirtmişlerdir. Elde edilen bu sonuç uygulama sonrasında her iki gruptaki öğretmen adaylarının bu boyuta yönelik görüşlerinde yanılgılarının olduğunu ortaya koymakla birlikte; bu yanılgının Grup I de Grupta II’ye göre daha fazla oranda azaldığını da ortaya koymaktadır. Mevcut görüşler aşağıdaki alıntılarda da örneklenmektedir.

Sosyal ve kültürel olarak etkilenir. Köylü ve şehirli veya farklı ülkelerin insanları farklı yaşam koşulları için bilgi üretirler. Grup I -Ö2 (uyg. sonr.)

Bilim tabii ki sosyal ve kültürel değerleri yansitabilir ama bunun yanında evrenseldir de bence. Çünkü herkesin yararına kanıtlanabilir bir bilgi. Grup II -Ö62 (uyg. önc.)

Elde edilen sonuçlar öğretmen adaylarıyla yapılan görüşmelerde de elde edilmiştir. İlgili alıntılar aşağıda örneklenmektedir.

A: Bilim evrensel midir yoksa sosyal kültürel değerlerden etkilenir mi?

Ö4: Günümüzde evrenseldir. Eskiden kültüre ve yaşantıya etki yoktu, ama şu an radyo internet televizyon olduğu için her türlü bilgiye ulaşabiliyoruz. Ama eskiden hiçbir şeyden haberleri olmuyordu.

Ö18: Edison ampulü bulurken kaç kez deneme yapmış. Burada karısı etkili olmuş.

Ö5: Teorik de sosyal-kültürel değerler etkilememeli, ama pratikte etkiler.

\section{Sonuç ve Tartışma}

Araştırmadan elde edilen sonuçlar öğretmen adaylarının bilim doğasıyla ilgili literatürde yeralan farklı yanılgılara sahip olduklarını ortaya koymaktadır. Araştırmadan elde edilen sonuç doğrudan-yansıtıcı yaklaşımla gerçekleştirilen öğretimin, kavram yanılgılarının giderilmesi konusunda dolaylı yaklaşıma göre daha etkili olduğunu ortaya koyar niteliktedir.

I. gruptaki öğretmen adaylarının tamamı uygulama öncesinde deneyin gerekli olduğunu belirtirken; uygulama sonrasında öğretmen adaylarının \%22'sinin bu konudaki görüşlerinin değiştiği görülmektedir. II. gruptaki öğretmen adaylarının tamamı ise uygulama öncesinde deneyin gerekli olduğunu; uygulama sonrasında ise öğretmen adaylarının \%10’unun gözlem yapılarak da sonuca ulaşılabileceği düşündükleri tespit edilmiştir. Araştırmadan elde edilen bu sonuç öğretmen adaylarının bilimsel bilginin elde edilmesi sürecinde deneylerin rolünün oldukça önemli olduğunu düşündüklerini de ortaya koyar niteliktedir. Buna karşın McComas (2000) deney yapmanın fendeki en kullanışlı araç olduğunu, fakat tek rota olmadığını; birçok bilim insanının bilgiyi ilerletmek için deneysel olmayan teknikleri de kullandığını belirtmektedir. $\mathrm{Bu}$ bağlamda öğretmen adaylarının bilimsel bilginin deneysel doğasına ilişkin görüşleri hem uygulama öncesi hem de sonrası açısından değerlendirildiğinde her iki grupta da yanılgıların 
olduğu görülmektedir. Nitekim bu yanılgının uygulama sonrasında azaldı̆̆ı, her iki gruptaki öğretmen adaylarının konuya ilişkin farklı görüşler ortaya attıkları görülmektedir. Elde edilen bu sonuçlara göre hem Grup I hem de Grup II'deki öğretmen adaylarının uygulama sonrasında, sayısı azalsa da halen yanlış inanışlara sahip oldukları söylenebilir.

Araştırmada Grup I ve Grup II'deki öğretmen adayları uygulama öncesi ve sonrasında teori ve kanunların birbirinden farklı olduğunu düşünürken; aralarında hiyerarşik bir ilişki olduğunu da düşünmektedirler. Benzer sonuçlar Dickinson, Abd-El Khalick ve Lederman (2000) öğretmen adaylarıyla yapmış oldukları araştırmada da tespit edilmiştir. Araştırmada elde edilen bu sonucun yanı sıra grup I ve grup II’deki öğretmen adaylarının, uygulama öncesi ve sonrasında teorilerin kanunları oluşturduğunu düşündükleri de görülmektedir. Elde edilen bu sonuçlar her iki grupta öğrenim gören öğretmen adaylarının teori ve kanunlara ilişkin bilgilerinde yanılgıların olduğunu da ortaya koyar niteliktedir. Akçay’nn (2011) yapmış olduğu araştırmada da öğretmenlerin bilimsel kanunların kanıtlanmış ve değişmeyen gerçekler olduğu yönünde yanılgılarının olduğu tespit edilmiştir. Bu bağlamda her iki gruptaki öğretmen adaylarının teori ve kanun arasındaki ilişkiyi kavrayamadıklarını, teori ve kanunun iki farklı bilgi türü olduğuna ilişkin görüşe sahip olmadıkları söylenebilir. Nitekim Ayvacı (2007), Ağlarcı (2014), Yenice vd. (2015) ve Özden ile Yenice’nin (2016) yapmış oldukları araştırmalarda da öğretmen adaylarının bilimsel teoriler ve kanunlara ilişkin kazanımlarının yeterli olmadığı tespit edilmiştir. Bu sonuçlara karşın Matkins, Bell, Irving ve McNall (2002) tartışmalı bir fen konusunda, doğrudan ve dolaylı yaklaşım kullanarak gerçekleştirdiği bilimin doğası öğretiminde; doğrudan yaklaşımla derslerin yürütüldüğü grupta uygulama sonrasında öğretmen adaylarının teorilerin yeni kanıtlarla veya mevcut kanıtların incelenmesi doğrultusunda değişebileceğini; ayrıca teori ve kanunun birbirinden farklı bilgi tipleri olduğunu düşündükleri tespit edilmiştir. Bu araştırmadan elde edilen sonuç özellikle I. grupta gerçekleştirilen uygulamanın bu boyuta ilişkin görüşlerin geliştirilmesi sürecinde yetersiz kaldığını ortaya koyar niteliktedir. Bu sonucun öğretmen adaylarının kavramlara ilişkin bilgilerinin yerleşmiş olmasından, kavramların sahip olduğu soyut yapıdan ve kavrama ilişkin birden fazla yanılgıya sahip olması ile ilişkili olabileceği düşünülmektedir. Özden ve Yenice’nin (2016) yapmış olduğu çalışmada ise fen bilgisi öğretmen adayları bilimsel kanun ve teorilerin fen bilimleri öğretim programında yer alması gerektiğini düşünürken; kendilerini bu kavramları öğretmede yetersiz gördüklerini ve bu konuda bilgilerinin olmadığını da belirtmişlerdir.

Araştırmada uygulama öncesi ve sonrasında Grup I ve Grup II'de öğrenim gören öğretmen adaylarının büyük bir çoğunluğu (\%91-\%100) bilimsel bilginin değişebilir nitelikte olduğunu belirtmişlerdir. Buna rağmen Grup I’de yer alan az sayıda öğretmen adayının aksi yönde görüş ortaya koydukları da görülmüştür. Elde edilen bu sonuç öğretmen adaylarının büyük bir çoğunluğunun bilimsel bilginin değişebilirliğine yönelik çağdaş bir bakış açısına sahip olduklarını da ortaya koyar niteliktedir. Ayrıca elde edilen sonuçlar Grup I'de daha fazla (\%96) oranda öğretmen adayının uygulama sonrasında bilimsel bilginin değişebileceğine yönelik görüş ortaya koyduklarını da göstermektedir. Yenice vd. (2015) yapmış olduğu araştırmada da fen bilgisi öğretmen adaylarının bilimsel bilginin değişebilirliğine yönelik gerçekçi bakış açısına sahip oldukları belirlenmiştir. 
Araştırmadan elde edilen bu sonuca karşın yapmış oldukları açıklamalarda öğretmen adaylarının görüşlerinde yanılgıların olduğu da görülmektedir. Buna göre her iki grupdaki öğretmen adaylarının teorilerin değişebilir, kanunların ise değişmez nitelikte olduğunu düşündükleri görülmektedir. Köksal’ın (2010) yapmış olduğu araştırmada da dokuzuncu sınıf fen lisesi öğrencilerinin, hem uygulama öncesi hem de sonrasında, teori ve kanun arasındaki yanılgıya sahip oldukları belirlenmiştir. Buna karşın farklı araştırmalarda benzeri yanılgının giderildiği de tespit edilmiştir. Lin ve Chen'in (2002) yapmış olduğu araştırmada tarihsel dokümanlar kullanılarak yapılan kimya öğretiminin, öğretmen adaylarının bilimsel gözlemlerin teori yüklü doğası ve teorilerin işlevine ilişkin daha yeterli görüşler ortaya koymalarına neden olduğu tespit edilmiştir. Benzer bir şekilde Metz’in (2002) yapmış olduğu araştırmada da uygulama sonrasında öğrencilerin teori ve kanunlara ilişkin mevcut yanılgılarının giderildiği tespit edilmiştir. Yip’in (2006) yapmış olduğu araştırmada uygulama öncesinde öğretmenlerin, teorileri mevcut durumların tam ve doğru açıllamaları olarak düşündükleri; uygulama sonrasında ise mevcut düşüncelerinin olumlu yönde farklılaştığg tespit edilmiştir. Bu araştırmadan elde edilen sonuç bilimsel bilginin değişebilir nitelikte olduğunu düşünen öğretmen adaylarının; söz konusu kavram "kanun” olunca aksini düşündüklerini ortaya koymaktadır. Bu bağlamda her iki grupta yer alan öğretmen adaylarının bilimsel bilginin değişebilirliğine ilişkin görüşlerinde yanılgıların olduğu söylenebilir.

Bilimde gözlem-çıkarım ilişkisine yönelik elde edilen sonuçlar her iki gruplarda öğrenim gören öğretmen adaylarının, bu konudaki görüşlerinin yeterli olmadığını ortaya koyar niteliktedir. Öğretmen adayları, bilim insanlarının birbirlerinden bağımsız bir şekilde yapmış oldukları farklı çalışmalar ve yöntemlerle verilerini topladıklarını düşünürken; ne uygulama öncesi ne de sonrasında mevcut verilerden çıkarımlar yapılarak sonuçlara ulaşılabileceğini ifade etmemişlerdir. Araştırmadan elde edilen bu sonuç Metin'in (2009) yapmış olduğu araştırmadan elde edilen sonuçla da paralellik göstermektedir. Bu araştırmadan elde edilen sonuç, uygulanan öğretim tasarımının gözlem-çıkarım ilişkisini kavrama konusunda yetersiz kaldığını gösterir niteliktedir. Elde edilen bu sonucun aksine, farklı araştırmalarda (Matkins vd., 2002; Küçük, 2006; Ayvac1, 2007; Ağlarcı ve Kabapınar, 2016) gözlem-çıkarım ilişkisinin yeterli bir şekilde kavratılabildiği tespit edilmiştir. Nitekim Özden ve Yenice'nin (2016) “süt etkinliği” bağlamında yapmış oldukları araştırmada da öğretmen adaylarının gözlem ile çıkarımın birbirinden farklı kavramlar olduğunu kavradıkları belirlenmiştir. Elde edilen sonuçların birbirinden farklı olmasının araştırma desenleri ve araştırmacıların sahip olduğu subjektif yapıdan kaynaklanabileceği gibi; uygulanan etkinliklerle de ilişkili olabileceği düşünülmektedir.

Bilimsel bilginin sosyal ve kültürel doğasına ilişkin yapmış oldukları açıklamalarda grup I’deki öğretmen adaylarının düşüncelerinin oldukça farklılaştığı görülmüştür. Uygulama öncesinde az sayıda öğretmen adayının bilimde sosyal ve kültürel değerlerin etkisinden söz ettiği, uygulama sonrasında ise bu sayının arttığ 1 tespit edilmiştir. Nitekim Matkins’in vd. (2002) yapmış oldukları araştırmada da uygulama sonrasında öğretmen adaylarının \%27'sinin, bilimsel bilginin sosyal ve kültürel doğasına ilişkin görüşlerinin geliştiği tespit edilmiştir. Grup II'deki öğretmen adaylarının büyük bir çoğunluğu ise hem uygulama öncesi hem de sonrasında 
bilimsel bilginin evrensel olduğunu belirtmişlerdir. Nitekim Akçay (2011) ile Hastürk vd. (2014) yapmış oldukları araştırmalarda da öğretmenlerin bilimsel çalışmaların sosyal ve kültürel değerlerden etkilenmediğini düşündükleri tespit edilmiştir. Farklı araştırmalardan elde edilen sonuçların grup II'nin sonuçlarıyla örtüştüğü görülürken; Yenice vd. (2015) fen bilgisi öğretmen adaylarıyla yapmış olduğu araştırmanın sonuçlarıyla da çeliştiği görülmektedir. İlgili çalışmada öğretmen adaylarının \%78'i bilimsel çalışmaların din, ahlak ve kültürel öğelerden etkilendiğini belirtmişlerdir. Araştırmalardan elde edilen farklı sonuçların, çalışmaların yürütüldüğü farklı örneklem grupları ile ilişkili olabileceği gibi; farklı reform hareketleriyle birlikte müfredatlarda yapılan değişikliklerle de ilişkili olabileceği düşünülmektedir.

Bilimsel bilginin nesnel doğasına ilişkin yapmış oldukları açılamalarda her iki gruptaki öğretmen adaylarının hem uygulama öncesi, hem de uygulama sonrasında, bilimsel bilginin elde edilmesi sürecinde kişisel özelliklerin yapılan çalışmalara yansıtıldığı düşüncesi içinde oldukları görülmektedir. Bu durum her iki gruptaki öğretmen adaylarının bu boyuta ilişkin görüşlerinin yeterli olduğunu da ortaya koyar niteliktedir. Elde edilen bu sonuca karşın Akçay’nn (2011) yapmış oduğu araştırmada öğretmenlerin bilimsel çalışmaların objektif olduğu, önceki bilgi ve deneyimlerin yapılan çalı̧̧malar üzerinde etkisinin olmadığı belirlenmiştir. Benzer sonuçlar Hastürk'ün vd. (2014) yapmış oldukları araştırmada da tespit edilmiştir. Araştırmalardan elde edilen bu farklı sonuçların çalışılan örneklem grubu ile ilişkili olduğu düşünülmektedir. Araştırmada elde edilen bu sonucun yanı sıra Grup I'deki öğretmen adaylarının uygulama öncesinde, bilimsel bilginin nesnelliğine ilişkin görüşlerinin daha yüzeysel, uygulama sonrasında ise daha kapsamlı olduğu görülmektedir. Uygulama sonrasında öğretmen adaylarının çoğunlukla hayal gücünün, ön bilginin ve kişisel özelliklerin farklı olması şeklinde cevaplar verdikleri tespit edilmiştir. Matkins'in vd. (2002) yapmış olduğu araştırmada da öğretmen adaylarının \%80'inin uygulama sonrasında mevcut görüşlerinin geliştiği; ayrıca bilimsel bilginin elde edilmesi sürecinde düşünce ve inanç sistemine yapmış oldukları vurgunun da arttığ belirlenmiştir. Muşlu’nun (2008) yapmış olduğu araştırmada ise uygulama öncesinde öğrenciler bilim insanlarının aynı bilimsel verilere bakarak neden farklı sonuçlara ulaştıkları ile ilgili yeterli düzeyde görüşe sahip değilken; uygulama sonrasında bilim insanlarının farklı bakış açılarının olduğunu düşündükleri tespit edilmiştir. Benzer bir şekilde Ağlarcı ve Kabapınar’n (2016) kimya öğretmen adaylarıyla yapmış oldukları araşıırmada da öğretmen adaylarının yaklaşık yarısı bilimin objektif bir süreç olduğunu belirtmişlerdir.

Araştırmada bilimsel bilginin yaratıcı doğasına ilişkin görüşlerin her iki gruptaki öğretmen adayları için uygulama öncesi ve sonrasında yeterli olduğu tespit edilmiştir. Dickinson’nn vd. (2000) yapmış oldukları araştırmada da öğretmen adaylarının, bilimsel bilginin yaratıı doğasına ilişkin yeterli görüşler ortaya koydukları tespit edilmiştir. Bu sonuçların aksine Küçük (2006), Matkins vd. (2002) ve Akçay (2011) yapmış oldukları araştırmalarda, uygulama öncesinde katılımcıların bilimsel bilginin yaratıcı doğasına ilişkin görüşlerinin yeterli olmadığı tespit edilmiştir. Bu sonucun çalışlan örneklem grubunun, araştırma desenlerinin ve araştırmacıların farklılı̆̆ından kaynaklanabileceği düşünülmektedir. 
Araştırmadan elde edilen sonuçlar genel olarak değerlendirildiğinde doğrudan-yansitıcı yaklaşıma dayalı öğretimin öğretim tasarımının (Grup I), öğrencilerde var olan bilimin doğası ve boyutlarıyla ilgili kavram yanılgılarının giderilmesinde, dolaylı yaklaşıma göre (Grup II) daha etkili sonuçlar ortaya koyduğu söylenebilir. Araştırmada bilimin doğası öğretiminde dolaylı ve doğrudan-yansıtıcı öğretim yaklaşımlarının etkililiğine ilişkin elde edilen bu sonuç, farklı araştırmalarda da tespit edilmiştir. Ayvacı'nın (2007) üç farklı grupta dolaylı, doğrudan-yansıtıcı ve tarihsel öğretim uygulanarak gerçekleştirilmiştir. Araştırmadan elde edilen sonuçlara göre her üç öğretim materyalinin de, adayların bilimin doğasının bazı unsurlarını diğerlerine oranla daha fazla öğrenmelerine katkı sağladığı tespit edilmiştir. Nitekim Çelik (2015) ile Erdoğan ve Köseoğlu'nun (2015) yapmış oldukları araştırmalarda da doğrudan yaklaşıma dayalı yürütülen bilimin doğası öğretiminin, öğrencilerin anlayışlarında kısmen de olsa değişime neden olduğu gözlemlenmiştir.

Araştırmadan elde edilen sonuçlar doğrultusunda bu konuda çalışacak olan araştırmalara şu önerilerde bulunulmaktadır;

- Öğrenci ve öğretmenlerin, bilimin doğası anlayışlarının yetersizlik nedenleri ayrıntılı bir şekilde analiz edilmeli ve bu nedenlerin giderilmesine yönelik çalışmalıdır.

- Bilimin doğasına eğitiminin, süreklilik arz etmesinden çok, müfredatın içerisine yaygınlaştırılarak uygulanması önerilmektedir.

- Bilimin doğası öğretiminde, farklı yaklaşımları disiplinler arası bir şekilde uygulamanın daha etkili olabileceği düşünülmektedir. 


\section{Kaynaklar}

Abd-El Khalick, F., \& Lederman, N.G. (2000). The influence of history of science courses on students' views of nature of science. Journal of Research in Science Teaching, 37(10), 1057-1095.

Abd-El Khalick, F. (2005). Developing deeper understandings of nature of science: the impact of a philosophy of science course on preservice science teachers' views and instructional planning. International Journal of Science Education, 27(1), 15-42, Doi: http://dx.doi.org/10.1080/09500690410001673810

Ağlarcı, O. (2014). Doğrudan-yansıtıcı yaklaşıma dayalı öğretimin kimya öğretmen adaylarının bilimin doğası görüşlerine etkisi. (Yayımlanmamış Doktora Tezi). Marmara Üniversitesi Eğitim Bilimleri Enstitüsü Ortaöğretim Fen ve Matematik Alanları Eğitimi Anabilim Dalı Kimya Öğretmenliği Bilim Dalı.

Ağlarcı, O., \& Kabapınar, F. (2016). Kimya Öğretmen Adaylarının Bilime ve Sözde Bilime İlişkin Görüşlerinin Geliştirilmesi. Amasya Üniversitesi Eğitim Fakültesi Dergisi, 5(1), 248-286.

Akçay, B. (2011). Fen ve teknoloji öğretmenlerinin bilimin doğasına yönelik inanışları. Trakya Üniversitesi Eğitim Fakültesi Dergisi, 1(1), 145-164.

Aslan, O. (2009). Fen ve teknoloji öğretmenlerinin bilimin doğası hakkındaki görüşleri ve bu görüşlerin sınıf uygulamalarına yansımaları. (Yayımlanmamış doktora tezi). Gazi Üniversitesi Eğitim Bilimleri Enstitüsü.

Ayvacı, H. Ş. (2007). Bilimin doğasının sınıf öğretmeni adaylarına kütle çekim konusu içerisinde farklı yaklaşımlarla öğretilmesine yönelik bir çalışma. (Yayımlanmamış doktora tezi). Karadeniz Teknik Üniversitesi Fen Bilimleri Enstitüsü.

Ayvacı, H. Ş., \& Özbek, D. (2015). Fen teknoloji toplum dersi kapsamında yapılan uygulamaların fen bilimleri öğretmen adaylarının bilimin doğası algılarına etkisi. Hasan Âli Yücel Eğitim Fakültesi Dergisi, 12(1), 93-108.

Boran, G. H., \& Bağ, H. (2016). The influence of argumentation on understanding nature of science. International Journal of Environmental \& Science Education, 11(6), 1423-1431. http://www.ijese. net/makale/213 adresinden alınmıştır.

Çelik, S., \& Bayrakçeken, S. (2006). The effect of a 'science, technology and society' course on prospective teachers' conceptions of the nature of science. Research in Science \& Technological Education, 24(2), 255-273, doi: http://dx.doi.org/10.1080/02635140600811692

Çelik, S. (2015). Açık ve yansıtıcı yaklaşımla bilimin doğası öğretiminin lisansüstü öğrencilerinin bilimin doğası anlayışlarına etkisi. Atatürk Üniversitesi Kazım Karabekir Eğitim Fakültesi Dergisi, (31), 125147.

Çıbık, A. S. (2016). The effect of project-based history and nature of science practices on the change of nature of scientific knowledge. International Journal of Environmental and Science Education, 11(4), 453-472.

Dickinson, V. L., Abd-El Khalick, F., \& Lederman, N. G. (2000). Changing elementary teachers' views of the nos: effective strategies for science methods courses. ED, 441-680.

Erdoğan, M. N., \& Köseoğlu, F. (2015). Explicit-reflective instruction of nature of science as embedded within the chemical equilibrium. Eğitimde Kuram ve Uygulama, 11(2), 717-741.

Friedman, A. J. (2006). Biological classification historical case studies: fostering high school students' conceptions of the nature of science. (Unpublished Doctoral Dissertation). Wayne State University, Detroit, Michigan. 
Göksu, V., Aslan, O., Özel, M., \& Şenel Zor, T. (2016). Açık-düşündürücü ve tarih temelli öğretimin fen bilimleri öğretmen adaylarının bilimin doğası anlayışları üzerindeki etkisi. Mustafa Kemal Üniversitesi Sosyal Bilimler Enstitüsü Dergisi, 13(34), 313-327.

Hastürk, H. G., Öztürk, N., Demir, R., \& Kartal, T. (2014). Farklı eğitim kademelerinde öğrenim gören öğrencilerin bilimin doğası ile ilgili görüşleri. Tarih Okulu Dergisi, 7(XVIII), 671-688.

İmer Çetin, N., \& Taşar, M. F. (2015). Using Concept Maps to Determine Pre Service Science Teachers Views About The Nature of Science. Eğitimde Kuram ve Uygulama, 11(4), 1185-1206.

İrez, S., \& Çakır, M. (2006). Critical reflective approach to teach the nature of science: A rationale and review of strategies. Türk Fen Eğitimi Dergisi, 3(2), 19-35.

İrez, S. (2006). Are we prepared? An assessment of preservicescience teacher educators'beliefs about nature of science. Science Teacher Education, 90, 1113- 1143, doi: 10.1002/sce.20156

Kahyaoğlu, E. (2004). Investigation of the preservice science teachers' views on science technology and society issues. (Yayımlanmamış Yüksek Lisans Tezi). Middle East Technical University.

Khishfe, R. F., \& Abd-El Khalick, F. (2002). Influence of the explicit and implicit inqury-oriented instruction on sixth graders' views of nature of science. Journal of Research in Science Teaching, 39(7), 551-578.

Khishfe, R. F. (2004). Relationship between students' understanding of nature of science and instructional context. (Unpublished doctoral dissertation). Graduate College of the İllinois İnstitute of Technology, Chicago, Illinois.

Khishfe, R.F., \& Lederman, N. (2006). Teaching nature of science within a controversial topic: integrated versus nonintegrated. Journal of Research in Science Teaching, 43(4), 395-418, DOI 10.1002/ tea. 20137

Köksal, M. S. (2010). The effect of explicit embedded reflective instruction on nature of science understandings, scientific literacy levels and achievement on cell unit. (Yayımlanmamıs Doktora Tezi). Middle East Technical University.

Kim, S. Y. (2007). Genetics instruction with history of science: nature of science learning. (Unpublished doctoral dissertation). The Ohio State University, Ohio, USA.

Küçük, M. (2006). Bilimin doğasının ilköğretim 7. sınıf öğrencilerine öğretmeye yönelik bir çalışma. (Yayımlanmamış doktora tezi). Karadeniz Teknik Üniversitesi Fen Bilimleri Enstitüsü.

Lederman, N. G., \& Abd-El Khalick, F. (1998). Avoiding de-natured science: activities that promote understanding of the nature of science. W.F. McComas (Ed.), The nature of science in science education: rationales and strategies (s.83-125), Netherlands: Kluwer Academic Publishers.

Lederman, N.G., Abd-El Khalick, F., Bell, R.L., \& Schwartz, R.S. (2002). Views of nature of science questionnaire: toward valid and meaningful assessment of learners' conceptions of nature of science. Journal of Research in Science Teaching, 39(6), 497-521, DOI: 10.1002/tea.10034

Lin, H. S., \& Chen, C. C. (2002). Promoting preservice chemistry teachers'understanding about the nature of science through history. Journal of Research in Science Teaching, 39(9), 773-792, DOI: 10.1002/ tea. 10045

Matkins, J. J, Bell, R., Irving, K., \& Mcnall, R. (2002). Impacts of contextual and explicit instruction on preservice elementary teachers' understandings of the nature of science. Proceedings of the Annual International Conference of the Association for the Education of Teachers in Science. https://eric. ed.gov/?id=ED465615 adresinden 04.06.2015 tarihinde edinilmiştir. 
McComas, Z. F. (2000). The role and character of the nature of science in science education. In W. F. McComas (Ed.), The principal elements of the nature of science: dispellingthe myths. Dordrecht, Boston, London: Kluwer Academic Publishers.

McComas, W. F., Clough, M. P., \& Almazroa, H. (2000). The role and character of the nature of science in science education. In W. F. McComas (Ed.), The nature of science in science education: rationales and strategies. Dordrecht, Boston, London: Kluwer Academic Publishers.

Mİlli Eğitim Bakanlığı (MEB) Talim ve Terbiye Kurulu Başkanlığı. (2006). İlköğretim Fen ve Teknoloji Dersi $(6,7,8$. Sınıflar) Öğretim Programı, Ankara.

Metz, D. J. (2002). Understanding the nature of science through the historical development of conceptual models. (Unpublished doctoral dissertation). University of Manitoba.

Metin, D. (2009). Yaz bilim kampında uygulanan yönlendirilmiş araştırma ve bilimin doğası etkinliklerinin ilköğretim 6. ve 7. sınıftaki çocukların bilimin doğası hakkındaki düşüncelerine etkisi. (Yayımlanmamış doktora tezi). Abant İzzet Baysal Üniversitesi Sosyal Bilimler Enstitüsü.

Muşlu, G. (2008). İlköğretim 6. sınıf öğrencilerinin bilimin doğasının sorgulama düzeylerinin tespiti ve çeşitli etkinliklerle geliştirilmesi. (Yayımlanmamış doktora tezi). Marmara Üniversitesi Eğitim Bilimleri Enstitüsü.

Nalçacı, İ. Ö., Akarsu, B., \& Kariper, A. İ. (2011). Bilimin doğası ve bilim tarhi dersinin fen bilgisi öğretmen adaylarının bilimin doğası hakkındaki bilgi ve görüşlerine etkisi. Selçuk Üniversitesi Ahmet Keleşoğlu Eğitim Fakültesi Dergisi, 32, 337-352.

National Research Council (NRC) (1996). National Science Education Standarts. Washington, DC: National Academy Press.

Oyman, Y. (2002). İlköğretim Fen Bilgisi öğretmenlerinin bilimin doğası hakkındaki anlayışlarının tespiti. (Yayımlanmamış Yüksek Lisans Tezi). Marmara Üniversitesi Eğitim Bilimleri Enstitüsü.

Özden, B., \& Yenice, N. (2016). Fen Bilgisi Öğretmen Adaylarının Bilimsel Kanun ve Teori Kavramlarına Yönelik Görüşleri: Nitel bir durum çalışması. İlköğretim Online, 15(4), 1090-1113.

Öztuna Kaplan, A. (2006). Fen bilgisi öğretmen adaylarının epistemolojik inanışlarının okul deneyimi ve öğretmenlik uygulamasındaki yansımaları: durum çalışması. (Yayımlanmamış doktora tezi). Marmara Üniversitesi Eğitim Bilimleri Enstitüsü.

Patton, M. Q. (2002). Qualitative research \& evaulation methods. London: Sage Publication.

Rivas, M. G. (2003). The nature of science and the preservice elementary teachers: changes in understanding and practice. (Unpublished doctoral dissertation). University of California, Santa Barbara.

Turgut, H. (2005). Yapılandırmacı tasarım uygulamasının fen bilgisi öğretmen adaylarının bilimsel okuryazarlık yeterliklerinden "bilimin doğası" ve "bilim-toplum-teknoloji ilişkisi” boyutlarının gelişimine etkisi. (Yayımlanmamış doktora tezi). Yıldız Teknik Üniversitesi Sosyal Bilimler Enstitüsü.

Wahbeh, N. A. K. (2009). The effect of a content-embedded explicit-reflective approach on inservice teachers' views and practices related to nature of science. (Unpublished doctoral dissertation). University of Illinois, Urbana, Illinois.

Yenice, N., Özden, B., \& Balcı, C. (2015). Fen Bilgisi ve Sınıf Öğretmeni Adaylarının Bilimin Doğasına Yönelik Görüsslerinin İncelenmesi. Erzincan Üniversitesi Eğitim Fakültesi Dergisi, 17(1), 237-281.

Yenice, N., \& Özden, B. (2016). Bilimsel Araştırma Bir Soru İle Başlar; Süt Etkinliği. Trakya Üniversitesi Eğitim Fakültesi Dergisi, 6(2), 153-158. 
Yip, D. (2006). Using history to promote understanding of nature of science in science teachers. Teaching Education, 17(2), 157-166, http://dx.doi.org/10.1080/10476210600680382

Yüce, Z., \& Önel, A. (2015). Fen öğretmen adaylarinin bilimin doğasini anlamalari ve evrim teorisini kabul düzeylerinin belirlenmesi. Electronic Turkish Studies, 10(15), 857-872.

Yücel Dağ, M. (2015). Kavram karikatürleriyle zenginleştirilmiş etkileşimli kisa tarihsel hikâyelerin bilimin doğasi öğretiminde kullanimi üzerine bir öz-inceleme. (Yayımlanmamaş Doktora Tezi). Gazi Üniversitesi Eğitim Bilimleri Enstitüsü. 